\title{
Éditorial
}

\section{La recherche en APA-Santé : perspectives pluridisciplinaires actuelles}

\author{
Pascale Leconte ${ }^{1}$ et Alain Varray ${ }^{2}$ \\ 1 Laboratoire CIAMS, UFR STAPS, Université Paris-Sud, 91405 Orsay cedex, France \\ 2 Laboratoire Movement To Health, UFR STAPS, Université de Montpellier 1, 34090 Montpellier, France
}

Le terme Activité Physique Adaptée (APA) est né au Québec dans les années 1970. L'APA est alors envisagée comme une alternative à l'éducation physique en direction des publics « à besoins spécifiques », l'objectif étant d'améliorer la condition physique, la qualité de vie et l'inclusion des personnes malades, handicapées, âgées ou exclues socialement. Ainsi, ces APS adaptées sont dispensées à des fins de prévention, de rééducation, de réadaptation, de réinsertion, d'éducation et/ou de participation sociale. Sous l'impulsion de Clermont Simard au Québec, puis de Jean-Claude De Potter en Belgique, les deux premiers présidents de l'IFAPA (International Federation of Adapted Physical Activity), le champ des APA se développe au sein des universités et est introduit en Europe à l'aube des années 1980. Dès lors, une formation universitaire spécifique APA se met en place au sein des UFR STAPS et se propage au fil des années sur le territoire français. Cette formation, présente sur plus de 35 sites universitaires aujourd'hui, a favorisé le recrutement de nombreux enseignants en APA, qui contribuent à développer la pratique physique et sportive dans des établissements ou associations prenant en charge des publics spécifiques. Les titulaires d'une Licence STAPS spécialité APA et Santé ${ }^{1}$ peuvent exercer dans des secteurs d'intervention très variés, allant du secteur sanitaire au secteur médico-social, en passant par les secteurs associatif, fédéral et judiciaire. Rapidement, l'offre de formation s'élargit, avec la création de diplômes européens et de Masters en APA-Santé, permettant l'accès à un niveau cadre ou coordonnateur en APA, pour la mise en place de programmes et projets en APA et Santé. En parallèle, un nouveau champ de recherche émerge peu à peu au sein des laboratoires STAPS, visant à établir une dialectique entre la recherche universitaire et ses applications

1 En 2007, la Conférence des Directeurs d'UFR STAPS en accord avec l'AFAPA, décident d'élargir le sigle APA à celui d'APA et Santé. concrètes dans les différents secteurs d'intervention de l'APA, répondant à deux préoccupations prioritaires : apporter les preuves scientifiques de l'intérêt et de l'efficacité de l'APA et donner des repères pertinents, cohérents et validés pour la mise en œuvre concrète sur le terrain.

Ainsi, depuis plus de 30 ans, c'est dans cette dialectique entre recherche et pratique, que les formations et les investigations en APA-Santé, portées par les UFRSTAPS en priorité, se développent de façon exponentielle afin de répondre au mieux aux problèmes de santé publique liés au vieillissement, à la santé et au handicap, ainsi qu'aux demandes spécifiques des établissements des secteurs sanitaire et médico-social. Les $\mathrm{XVI}^{\mathrm{e}}$ Journées d'Etudes Francophones en APA qui se sont déroulées à l'UFR STAPS d'Orsay du 29 au 31 mars 2012, avaient pour ambition de contribuer à cet objectif, au travers d'un thème central «La Formation et la Recherche en APASanté : Quels enjeux pour quelles populations cibles?». L'intérêt principal de ces journées d'études était de valoriser les recherches actuelles menées dans le domaine de l'APA-Santé par les enseignants-chercheurs au sein des Laboratoires STAPS, mais aussi par les enseignants en APA associés à des équipes de recherche, STAPS. Au final, ce sont 7 conférenciers de renommée internationale dans le domaine de l'APA-Santé, ainsi que 37 communicants qui sont venus présentés l'état de leurs travaux de recherche, apportant des éclairages scientifiques issus des Sciences de la Vie et des Sciences Humaines et Sociales, sur les enjeux des activités physiques et de l'exercice chez des populations cibles.

Ce numéro spécial comprend douze contributions sélectionnées par le comité scientifique, constitué de 24 spécialistes issus de différents champs disciplinaires. Nous les remercions vivement de s'être acquittés dans les délais impartis et avec sérieux, de cette tâche laborieuse qu'est l'expertise d'articles scientifiques.

Les dix premiers articles proposent des orientations cliniques et des revues de questions permettant de mieux 
comprendre le rôle de l'APA dans l'amélioration des performances et de l'état de santé de populations spécifiques. Des publics hétérogènes, mais en particulier des publics en situation de handicap moteur, se trouvent au cour de ces contributions : les patients hémiplégiques (Slawinski et al.), les patients lombalgiques chroniques (Durocher et al.), les blessés médullaires (Middernacht), les patients amputés du membre inférieur (Demets et al.), les athlètes handisport (Lepers et al.), les patientes anorexiques (Moscone et al.), les patients diabétiques (Mendelson et al.), les personnes porteuses de Trisomie 21 (Leti et al.), les sujets bruxomanes (Bernard et al.), et les personnes vulnérables au sens large (Lecocq et Dervaux). L'ensemble de ces contributions présente un intérêt majeur pour le secteur interventionniste. Les résultats mis en avant apportent en effet des éclairages nouveaux, que les praticiens pourront intégrer dans leur programmation afin d'adapter au mieux les modalités de pratique aux capacités et aux besoins spécifiques des publics encadrés et déterminer un dosage de l'exercice de plus en plus ciblé.

Les deux dernières contributions s'inscrivent dans une approche sociologique, avec comme objectif majeur d'identifier, à partir de la parole des patients, le rôle et l'enjeu de l'APA dans leur prise en charge thérapeutique. La première des deux questionne le sens et l'intérêt que peut revêtir l'APA chez des patients atteints du VIH en fonction d'un sentiment de vulnérabilité étroitement associée à la visibilité de sa pathologie (Thomas et al.). La deuxième met en évidence l'utilisation du sport comme processus d'ajustement à la maladie, chez des patients atteints de mucoviscidose (Fuchs et al.).

Nous espérons que ce numéro thématique sur la recherche en APA-Santé saura témoigner de l'importance grandissante de la recherche dans ce champ au sein de la communauté scientifique STAPS, d'une part, en donnant aux nombreux lecteurs de la revue un aperçu des études scientifiques récentes menées en France dans le domaine de l'APA-Santé, et d'autre part, encourageant les jeunes chercheurs et les laboratoires STAPS à poursuivre les recherches dans ce domaine.

Remerciements. L'organisation de ces $\mathrm{XVI}^{\mathrm{e}}$ Journées d'études n'aurait pu être possible sans le soutien de nos partenaires financiers (université Paris-Sud, région Île-de-France, Banque Populaire, Cap Vital Santé), de nos partenaires institutionnels présents sur les stands (Comité départemental Handisport 91, Comité départemental Sport Adapté 91, Idema Sport, SFP-APA, MixHandi-Capsur la Vie) et de nos partenaires locaux (Mission Handicap, Service Central Handicap et Etudes, CESFO, Centre Urban Foot). Nous tenons à les remercier de s'être associés à cette manifestation scientifique. 


\title{
Editorial
}

\section{Research in APA: Current multidisciplinary perspectives}

\author{
Pascale Leconte ${ }^{1}$ and Alain Varray ${ }^{2}$ \\ ${ }^{1}$ Laboratory CIAMS, UFR STAPS, University Paris-Sud, 91405 Orsay cedex, France \\ ${ }^{2}$ Laboratory Movement To Health, UFR STAPS, University Montpellier 1, 34090 Montpellier, France
}

The term adapted physical activity (APA) was first used in Québec in the 1970s to define an alternative to physical education for people with "special needs". The aims of APA are to improve the physical fitness quality of life and social inclusion of those with limiting conditions, such as people with disabilities or impaired health, the elderly and the socially excluded. Specifically designed physical activity programs can therefore be prescribed for purposes of prevention, rehabilitation, education and/or integration.

Under the leadership of Clermont Simard in Quebec and Jean-Claude De Potter in Belgium, who were the first two presidents of the International Federation of Adapted Physical Activity (IFAPA), the field of APA began to develop in universities and was introduced to Europe in the early 1980s. Since then, APA curricula have been constructed in French universities, mainly through their Schools of Sport Sciences (UFR-STAPS), and today APA degrees are offered on more than 35 university campuses. This growth has facilitated the recruitment of qualified APA instructors by a wide range of institutions and associations promoting APA programs for special needs individuals. A professional with a Bachelor's degree in APA can lead physical activity sessions in a variety of sectors of intervention, such as hospitals, specialized centers, non-profit organizations, sports federations and even court-appointed programs. European-level degrees and Master's degree programs also now prepare professionals to implement and manage APA programs and projects. In parallel, a new field of research is gradually emerging in UFR-STAPS laboratories to bridge the gap between academic research in APA and its practical applications in these various areas of intervention. The research addresses two main priorities: making APA an evidence-based discipline and establishing relevant benchmarks for practical implementation in the field. Thus, for over 30 years, this dialogue between APA researchers and practitioners has been growing exponentially, in large part due to the training and investigations conducted by the UFR-STAPS, and today adapted responses can be offered to address a range of public health problems, as well as the specific requirements of hospitals and specialized institutes. The 16th Conference on APA Training and Research, which was held at the UFR-STAPS of Orsay from March 29 to March 31, 2012, contributed to this objective through its central theme: "Training and research in APA: which issues for which populations?" The main focus of the conference was to present the current research in APA conducted by STAPS laboratory researchers in collaboration with the APA instructors associated with these research teams. Seven internationally renowned speakers in the field of APA and 37 other speakers presented their work, providing both new insights from rich data sets in the life sciences, humanities and social sciences and further evidence of the benefits of physical activity and exercise for target populations. This special issue includes 12 contributions selected by the scientific committee, which comprised 24 experts from various disciplines. We thank them for having completed this laborious task of evaluating research articles in such a timely and serious manner.

The first ten contributions cover clinical orientations and review some of the major issues in APA today with regard to its role in improving health and performance in specific populations. A heterogeneous population is at the heart of these contributions, although people with motor disabilities are prominent; the range includes hemiplegic patients (Slawinski et al.), chronic low back pain patients (Durocher et al.), patients with spinal cord injury (Middernacht), lower limb amputees (Demets et al.), disabled athletes (Lepers et al.), anorexic patients (Moscone et al.), diabetic patients (Mendelson et al.), individuals with Down Syndrome (Leti et al.), patients presenting bruxism (Bernard et al.), and those with generally poor health (Lecocq \& Dervaux). These contributions are of major interest for practitioners because they bring new insights that can be incorporated into their programming to better adapt conditions to the capabilities and needs of the target populations 
and to better adjust the intensity and quantity of the targeted exercises. The last two contributions present a sociological approach, with the main objective of giving voice to patients in order to identify the role and impact of APA programs in their therapeutic management. The first examines the meaning and value of an APA program for HIV patients, who often feel vulnerable because of the visibility of this pathology (Thomas et al.). The second highlights the use of sport as part of the process of adjusting to disease, which is explored in patients with cystic fibrosis (Fuchs et al.). We hope that this special issue will testify to the growing importance of APA research within the STAPS community, first, by giving readers an overview of the studies recently conducted in
France in this field and, second, by encouraging young researchers and STAPS laboratories to continue APA research.

Acknowledgement. The organization of the 16th Conference on APA Training and Research would not have been possible without the support of our financial partners (Université Paris-Sud, Ile de France, Banque Populaire, Cape Vital Santé) and our institutional and local partners (Comité Départemental Handisport 91, Comité Départemental Sport Adapté 91, Idema Sport, SFP-APA, MixHandi-Capsur la Vie, Mission Handicap, Service Central Handicap et Etudes, CESFO, Centre Urban Foot). We thank them for their commitment to this scientific event. 